\title{
COMMUNITY ECONOMIC DEVELOPMENT AND LOW-INCOME HOUSING DEVELOPMENT
}

\author{
PaUl G. GarRitY*
}

\section{INTRODUCTION}

Although the ideologists of community economic development disagree among themselves as to the significance, meaning, and objective of the "community" part of the equation, ${ }^{1}$ both they and the practitioners seem to approach near unanimity in equating economic development with business development. ${ }^{2}$ Even so, questions must be answered. How did this agreement come about? Does this consensus as to business development (whatever that means) as a strategy for achieving community economic development exclude or reject alternative or additional methods? Would low-income housing development be an effective and efficient alternative or additional way to bring about community economic development?

The following analysis will respond to these issues and will also discuss some of the problems of "community" that should be considered when the decision, however arrived at, is made to develop housing for low-income individuals and families.

\section{I}

The Terminology of Development

\section{A. Defining Community Economic Development}

To attempt to construct a dictionary-like definition of a term such as "community economic development" invites obfuscation and redundancy. The two elements of the term, "community" and "economic development," can be interpreted only in relation to specific contexts, and the context under consideration is rather unique both historically and contemporaneously.

\section{r. A Suggested Historical Perspective ${ }^{3}$}

The historical method to a large extent involves comparative factual analysis, and there have been many scholarly narratives published concerning the grim urban life of immigrant ethnic groups over the past 100 years. ${ }^{4}$ There is substantial doc-

- Assistant Professor of Law, Boston College; Urban Fellow, Harvard Law School.

1 Compare the more radical view proposed by Rosenbloom, Corporations for Urban Development, in Soctal INNovation IN THE CITY 16I ( $R$. Rosenbloom \& $R$. Marris eds. I969), with the traditional approach espoused by Allen, Making Capitalism Work in the Ghettos, Harv. Bus. Rev., May-June I969, at 83 .

${ }^{3}$ For a catalog listing what the practitioners are doing, see U.S. DEP'T of JUSTICE, CoMmunitY Relations Service, New Minority Enterprises (I969) [hereinafter cited as New Minority ENTERPRISES].

"The term "suggested" is employed so the reader will not regard the views offered as conclusive. The few observations are, of course, superficial, although they have been gleaned from extensive readings in this area.

¿See, e.g., The City in American Life (P. Kramer \& F. Holborn eds. 1970). 
umentary evidence to support the facts that institutional discrimination against and economic repression of such groups continued until, by virtue of the size of the vote that could be mustered, they seized or participated in political power. ${ }^{5}$ Political power, then as now, has its rewards to those wielding it, including not inconsiderable pieces of the employment, housing, and other municipal services action. Although there have always been urban racial ghettos, only with the mass migrations during and after World War II have blacks, by virtue of their numbers, constituted a potentially significant political force in cities. ${ }^{\circ}$ Moreover, this potential did not become realized until the I960's when militants and poverty program organizers created in black neighborhoods a sense of racial identity and community, which had not existed in ethnic ghettos, and liberals urged recourse to the ballot box. ${ }^{7}$ Unfortunately, by that time the pay-offs generated by political control had declined in quality and quantity. Civil service legislation had insulated much municipal employment from the spoils system, and the pork barrel was fiscally lean. Most cities were nearly bankrupt and too impotent politically to tap the resources of the white suburban rings or to share in the revenues of the federal government which had pre-empted the field for municipal tax gatherers. There had occurred an imbalance, aggravated to an acute degree in the inner cities, between resources and human, physical, and social needs which, to many community leaders, meant developing an indigenous economic base to satisfy these needs. ${ }^{8}$

\section{In Terms of Goals and Strategy}

What are these needs? Any comprehensive study considering the "urban crisis," such as the Kerner Report, restates the problems and rephrases the solutions." In the final analysis, any cycle of poverty and deprivation-and that is the inner-city "crisis"- can be broken with money. It takes money to provide high paying employment, to devise an adequate income-maintenance program, to furnish adequate housing, education, and social services, and, of course, to develop a community

\footnotetext{
"Oscar Handlin has observed with respect to the Irish immigrants in the 1850's: "They faced cxhausting difficulties in making a place for themselves in the city's economic life. . . The degree of their penetration into any trade varied inversely with its desirability. . . . Generally, the only opportunity for aliens to figure in commerce or finance grew out of the patronage of their own communitics." Handlin, Boston's Immigrants: The Economic Adjustment, in id. at 82-84.

${ }^{6}$ Report of the National Advisory Commisston on Crvil Disorders il5-20 (1968) [hereinafter cited as the KERNER REPORT].

${ }^{7}$ Id. at I04-I2.

${ }^{8}$ Advisory Commission on Intergovernmental Relations, Urban America and the Federat System 7-II (1969). See also L. Ecker-Racz, The Politics and Economics of State-Local Finance I95-211 (x970). However, many community leaders argue that the only path to power is the political one and that economic development is diverting and divisive.

The confirmed cynic would concur with Dr. Kenneth Clark, who, in testimony before the Kerner Commission, observed: "I read that report ... of the I919 riot in Chicago, and it is as if I were reading the report of the investigating committee on the Harlem riot of 1935 , the report of the investigating committee on the Harlem riot of 1943 , the report of the McCone Commission on the Watts riot. I must again in candor say to you members of this Commission-it is a kind of Alice in Wonderland with the same moving picture reshown over and over again, the same analysis, the same recommendations, and the same inaction." Quoted in KERNER REPORT 265.
} 
economically. One very obvious method or strategy of making money is business development, and, not surprisingly, Black Power became Green Power. ${ }^{10}$ The theory seems to be that with the development of business will come more and improved employment opportunities, increased income, and profits which can be rolled over into more business development or community services unobtainable from municipal treasuries. The extent of community involvement in the direction of this process would depend on communities themselves. With few operating exceptions, this is what community economic development has come to mean in practice. ${ }^{11}$

\section{B. An Analysis of Inner-City Business Development}

\section{In Operation}

The slogans adopted by inner-city business developers include "Black Capitalism," "Minority Entrepreneurship," and "Community Economic Development." One current federal assistance program contemplates the establishment of minority enterprise small business investment companies (MESBIC's), ${ }^{12}$ and possible federal legislation is entitled the Community Self-Determination Act. ${ }^{\mathbf{1 3}}$ With two exceptions, ${ }^{14}$ however, federal financial assistance is in the form of direct loans or loan guaranties and is allocated to the development of minority-owned small businesses. To be sure, there exist other federal efforts which respond to the non-money needs of inner-city entrepreneurs, but such programs rely primarily on the voluntary participation of the private sector. ${ }^{15}$ One exception, called title I-D Special Impact

\footnotetext{
${ }^{10}$ See DeLorean, The Problem, in Blacr Economic Development 7, r0-12 (W. Haddad \& G. Pugh eds. 1969).

${ }^{11}$ New Minority ENTERPrises, supra note 2. The Center for Economic Development, 56 Boylston Street, Cambridge, Massachusetts, maintains a comprehensive and up-to-date inventory of the activties of economic development ventures, and the records at the Center confirm this fact.

${ }^{12}$ As of August I970, there were I6 MESBIC's licensed and in operation. OMBE OuTLook, Aug. I970, at Ix.

${ }^{10} \mathrm{~S}$. 3875 , 90th Cong., $2 \mathrm{~d}$ Sess. (1968). The most astute analysis of this legislation is contained in Miller, Community Capitalism and the Community Self-Determination Act, 6 HARv. J. LEGIS. 413 (I969).

${ }^{16}$ The Public Works and Economic Development Act of 1965,42 U.S.C. $\$ 3$ I2I (Supp. II, I967), and programs funded under its authority, should not be considered an exception since few ghettos, when combined for eligibility purposes with outer-city areas, are not sufficiently underdeveloped to receive such program grants and loans. However, technical assistance funding has been provided to ghetto entrepreneur assistance groups under this legislation.

${ }^{15}$ For a complete listing, consult U.S. Dep'T of CoMmerce, OfFice of Minority ENTERPRISE, Spectal Catalog of Federal Assistance Programs for Minority Business Enterprises (I969).

${ }^{10}$ This program, administered by the Office of Economic Opportunity, has been described as "a new experimental program designed to promote community-based economic development as a means of making a measurable impact upon chronic unemployment, dependency and community tensions in urban areas of high concentration of poverty and rural areas of high out-migration. This program provides substantial grants to development corporations representative of special impact areas. These grants may be used for a variety of investment programs which will create jobs for poverty area residents, develop managerial and entrepreneurial skills, and create opportunities for participation in ownership of production and commercial facilities by poverty areas residents. Community corporations can guarantee loans and provide technical assistance to new and existing businesses and can themselves participate in an enterprise on an equity basis." Id. at $8 \mathrm{r}$.
} 
program, ${ }^{16}$ furnishes substantial, but inadequate, funding for broad economic development purposes to community groups which, in most cases, have engaged in small business development. The other exception involves community development corporations being established and operated as component programs of local Model Cities agencies, and they have followed the pack in channelling their activities into small business development. ${ }^{17}$

\section{A Critique}

Inner-city business development is obviously not the most direct method of generating employment and profits or of increasing incomes. The optimum strategies would perhaps be job creation by subsidies, income maintenance programs, and grants for municipal services, but ghetto leaders view this approach, and accurately so, as politically and fiscally unattainable. However, what of the efficiency of the indirect strategy of business development and, in this case, small business development, in achieving these goals ? ${ }^{18}$ As contrasted with numbers of businesses established, how much minority employment is created, say, for each million dollars of SBA appropriations allocated to minority entrepreneurship ventures? What is the quality and duration of such employment? How much leakage is there-that is, employment of those already adequately employed or of non-minority group members? How much profit is actually generated and what portion of it benefits others in addition to the entrepreneur himself? ${ }^{19}$ It has been pointed out that the environment of inner-city neighborhoods is improved by the establishment of, for example, a pharmacy where there was none before, but is this improvement neutralized if in fact the black pharmacist must maintain prices at high levels to compensate for the increased insurance and other costs of doing business in the ghetto ${ }^{20}$ In sum, if the process of economic development must be accomplished indirectly, is small business development the way, or even a way, to go about it?

One alternative strategy for small business development would be the location of larger business, probably industrial and commercial, in the inner city. Here, the pay-offs to the community are more ascertainable and substantial. ${ }^{21}$ Unfortunately, the capital and expertise required for such undertakings are not usually available to minority entrepreneurs and require government and private sector assistance. Moreover, the federal government is usually not interested in large enterprise development unless some (other than minority) national interest is at stake and in-

\footnotetext{
${ }^{17}$ Demonstration Cities and Metropolitan Development Act of 1966, 42 U.S.C. $\$ 330$ (Supp. II, 1967).

${ }^{18}$ For an appraisal along these lines, see S. Levitan \&\& R. Taggart, Developing Business and Entrepreneurs in the Ghettos, Apr. 17, 1969 (unpublished paper prepared for the Community Self-Determination Steering Committee).

10 Id. at 32 .

${ }^{20}$ The problems of ghetto pharmacies are outlined in The Ailing Drugstore: Looking for a Cure, BLACK ENTERPRISE, Jan. I97I, at 28. The harsh facts of ghetto business life are catalogued in F. Coles, An Analysis of Black Entrepreneurship in Seven Urban AREas (I970).

${ }^{21}$ However, there are pitfalls with this approach. See S. SETHI, Business Corporations and the Black Man; An analysis of Social Conflict: The Kodar-Fight Controversy (1970).
} 
sufficient state and local incentives are available to offset the economic risks to large corporations establishing a ghetto subsidiary. ${ }^{22}$

\section{II}

\section{The Strategy of Low-Income Housing Development}

Although the housing development industry as such is fragmented and has at times been characterized as "chaotic," 23 it is certainly a "business" to those who engage in it. Yet it is considered by many observers as something unto itself, and this sentiment is reflected in federal policy and programs. ${ }^{24}$ How does "housing development" compare with "business development" as a strategy of community economic development? ${ }^{25}$

\section{A. Financial and Impact Leveraging}

The general goal of economic development presupposes that inner-city communities are undeveloped or, more likely, underdeveloped. There are insufficient local financial resources, and the strategy of business development takes this into account by leveraging government and private sector monies to secure most of the expenses of business development. ${ }^{26}$ However, in most cases the ghetto entrepreneur must and should ${ }^{27}$ furnish an amount of venture capital, although. some private organizations have been formed to furnish the usual owner's investment. Because of tax shelters available with housing development, it is quite possible and desirable to arrange for outside infusions of venture capital and, depending upon the arrangement worked out between a community sponsor and equity investors, to have the venture capitalist pay for the privilege of investing. ${ }^{28}$ Moreover, the sources and amounts of government and private financing for low-income housing development are greater than those available to small business developers under current and foreseeable federal priorities. ${ }^{29}$

\footnotetext{
${ }^{33}$ See Tabb, Government Incentives to Private Industry to Locate in Urban Poverty Areas, 45 LAND ECON. 392 (I969).

${ }^{23}$ See G. Beyer, Housing AND Soctety 225-26 ( $\mathrm{g}^{6} 65$ ), where the author contrasts the automobile and homebuilding industries.

26 For example, SBA loans cannot be used for real estate investment.

${ }^{25}$ Some community economic developers are interested. See Morey, Housing and High Leverage Innovating Financing as a Start-Up Point for Community Economic Development, Apr. I970 (unpublished paper prepared for the Center for Community Economic Development).

${ }^{20}$ See generally McNeish, Whete Does the Money Come From?, in Black Economic Deveropment, supra note 10 , at 85 .

"Interpret "should" from the perspective of having one's own stake in the business and because of the reality that excessive debt may very well spell business failure.

${ }^{28}$ For the details, consult Gabinet \& Coffey, Housing Partnerships: Shelters from Taxes and Shelters for People, 20 CASE W. REs. L. REv. 723 (I969). Surrey, Tax Incentives as a Device for Implementing Government Policy: A Comparison with Direct Government Expenditures, 83 HARv. L. REv. 705 (1970), and Ritter \& Sunley, Real Estate and Tax Reform: An Analysis and Evaluation of the Real Estate Provisions of the Tax Reform Act of 1969, $30 \mathrm{MD}$. L. REv. 5 (1970), both present convincing critiques of the efficiency and appropriateness of the tax shelter in producing housing-but housing is produced where none might be otherwise.

${ }^{20}$ Another complete listing is contained in Welfeld, A New Eramework for Federal Housing Aids,
} 
With housing development, the beneficial impact on the community as a whole is potentially greater than with business development. Employment related to housing development and resulting job skills will be generated, the incomes of those paying less for better housing will in effect be increased, and predictable profits, which can in turn be allocated to any number of community purposes, will occur. ${ }^{30}$ Moreover, one possible goal of business development would be to obtain profits for improved housing; when emphasis is directed at housing development, this result can occur at an earlier stage.

\section{B. The Certainties of Housing Development}

Perhaps the main advantage of housing development contrasted with business development is that its variables can be calculated with reasonable certainty, including the effects of both inflation and government red tape. The costs of land, construction, and maintenance can be determined in advance, and these expensesand the funding possible under government subsidy programs-can be fed into a computer to obtain feasibility and other desired information. ${ }^{31}$ Moreover, not only is there a relatively certain demand for the product, but the dream of most fledgling businessmen, a sheltered market, ${ }^{32}$ would be more than fully realized; for the market in which the low-income housing developer operates is also a subsidized one.

\section{Possible Activities by Community Development Groups}

Most non-private sector low-income housing development has been accomplished by not-for-profit sponsors, ${ }^{33}$ (in many cases religious organizations) with varying degrees of community participation, but rarely has a community group as such functioned as a developer. Most community organizations formed to carry out "housing" activities usually do just that, and their focus is predictably tenant-oriented in the sense of organizing and counselling tenants rather than working on development. A few "community economic development" organizations engage in housing development in addition to their business development activities.

A certainly unique example, but relevant as a model, of a community development organization conducting low-income housing development would be the BedfordStuyvesant Restoration Corporation (BSRC), which also makes loans and provides management assistance to minority entrepreneurs. ${ }^{34}$ BSRC operates at several housing

69 CoLtm. L. REv. I355 (I969). Although the current administration has included mobile homes within the statistics of housing produced to meet announced goals, the target levels have not been cut back.

${ }^{80}$ See Gabinet \& Coffey, supra note 28 , as to the predictability and amounts of "profits" available.

${ }^{81}$ Comprehensive computer analyses are contained in R. O'BLOcK \& R. Kunen,, AN Economic ANalysts of the Housing and Urban Development ACT of I968 (1970).

82 A cause of many inner-city entrepreneurial failures, guesting rather than assessing "the market," is now being remedied by groups conducting sophisticated market studies. See, e.g., CENTER CrTY, BustNess and Investment Opportuntties in Central Boston (Boston Urban Foundation, 1969).

${ }^{83}$ Apparently there has been little success by such groups. The story recounted in P. NiEBanck \& J. Pope, Restdentiat Refabiltratton: The Pitpalls of Non-Profit Sponsorship (I968), is all too typical.

34 The author spent nine weeks during the summer of 1970 on the legal staff of BSRC as part of an urban legal studies fellowship program. 
developments levels. It acquires deteriorated properties, rehabilitates them, arranges financing, and resells these properties to residents. It assembles sites and develops new housing to be managed by tenant groups. BSRC also functions as a general contractor and furnishes training and bonding for minority subcontractors. Where BSRC does not possess an in-house development competency-for example, to put together detailed architects' plans-it farms out such work to experts managed by or staffed with blacks. Unfortunately, BSRC is a showcase operation, and few community development groups have such expertise or, more importantly, the access to resources to approximate its activities. ${ }^{35}$

\section{III}

\section{Impediments to Low-Income Housing Development}

Aside from what could be included under the catch-all term of "risk," the two most significant obstacles to successful inner-city entrepreneurial development are difficulties in obtaining financing and the fact of less than adequate managerial skills. It is important to understand how much of a problem these two factors present as well as to recognize some additional difficulties peculiar to the development of low-income housing.

\section{A. Financing}

As with other business development, for-profit housing development requires equity investment, or a down payment, usually calculated as a percentage of funding expected to be made available by financing sources. Housing development also demands certain start-up resources, which have come to be known as "seed money."

\section{The Need for and Sources of Seed Money}

Housing development seed money is usually necessary to pay for organizational expenses and determinations of feasibility-in sum, to package a "deal" eligible for financing. ${ }^{36}$ This process is analogous to that in which a minority entrepreneur would engage prior to and while preparing his application for a business loan. With the small businessman, however, there are fewer factors to consider and less detail to document, perhaps because the detail is not ascertainable. Moreover, the entrepreneur is not required to enter into commitments both to determine and to control costs-such as expenses for architects' drawings and site options. The alternatives available to a housing development group seeking seed money are quite limited. Limited financing from private sources may be available. In some cases, especially with not-for-profit sponsors, the funding comes in the form of charitable contributions. Another possibility is entering into a joint venture with a private developer who will

\footnotetext{
${ }^{35}$ For a summary description of BSRC's organization and activities, see Note, Commtnity Development Corporations: Operations and Financing, 83 HaRv. L. REv. I558, I650 (I970).

${ }^{80}$ See generally Berger, Goldston \& Rothrauff, Slum Area Rehabilitation by Private Enterprise, 69 CoLUM. L. REv. 739, 749 (I969).
} 
make advances but nòt without some quid pro quo. A third alternative, which may be available to community groups funded under the Model Cities or Special Impact programs, is to request government monies to pay for these start-up expenses.

\section{The Need for and Sources of Equity Investment}

With housing development, the amount of equity capital required is usually proportionately less than that necessary with business development, perhaps because of the existence and nature of the security available in all cases. There are techniques available for reducing it still further. With private sector housing development, the developer either furnishes the equity himself or solicits investment from private sources. Ghetto groups retain this option and also have the possibility of soliciting funding from community residents as one way of assuring participation and a stake in the outcome. Another alternative available to community groups is seeking equity funding from the National Housing Partnership. ${ }^{37}$ The Partnership was formed for a variety of additional purposes, including providing seed money and technical assistance, but the primary reason for its existence is to furnish equity funds for federally-assisted, low-income housing development. However, this equity investment is not "free" and may have to be considered as a private source, depending upon the bargaining stance the Partnership assumes as to a proper return on its equity investment. . $^{38}$

\section{The Need for and Sources of Financing}

In the private housing development industry, financing is classified as construction or mortgage, and quite often the same source provides both types. With low-income housing development, the source in both cases depends upon government assistance, and the problem is not availability, even if the existence of this assistance is assumed, but rather feasibility. The solution is to piggyback as many government programs as possible to reduce consumer costs to within governmental assistance eligibility limits and thus make a project feasible. ${ }^{39}$ In other words, government insurance and purchase of a mortgage may induce a commercial lender to make financing available, but, because of high construction costs, interest subsidies alone may be insufficient to reduce rents to within limits administratively allowable for low-income families, and rent supplements would be required. The developer must then determine whether there are sufficient governmental appropriations for all of these housing programs since failure to qualify for only one of them may destroy the entire project's feasibility.

\section{Incidental or Indirect Sources of Funding}

In some locations, low-income housing is simply not feasible even with sufficient

\footnotetext{
${ }^{\mathrm{at}}$ Housing and Urban Development Act of 1968, 42 U.S.C. $\$ \S 3931-40$ (1970).

${ }^{88}$ In other words, will the Partnership drive as hard a bargain as a private investor?

so Welfeld, supra note 29 , at 1360 n.I9.
} 
"direct" federal assistance by way of mortgage insurance, interest subsidies, rent supplements, and the like. There are, however, "indirect" ways of reducing costs to make impossible projects possible and to lessen expenses for possible developments. For instance, an obvious tactic commonly used is to secure land which has been reduced or written down in price with urban renewal funds. In addition, Department of Labor grants might be obtainable to subsidize construction costs as well as to influence hiring of minority construction workers. Department of Justice funding could be sought to provide security to a construction site, reducing that cost and perhaps lessening insurance expenses. To summarize, other government programs, quite unrelated to housing, might be piggybacked depending upon the ingenuity of the community sponsor and the malleability of the federal bureaucrats.

\section{B. Technical Expertise}

As with financing, the technical aspect of housing development might be subdivided into three areas which could cause problems for a community group engaged in producing low-income housing.

\section{x. Development Skills}

Perhaps the best way to characterize this nebulous competence would be to denote it as the ability to put together deals. It is very similar to the necessary skill termed management ability, but yet it is something more. It comprises a series of non-technical abilities and, more importantly, experience-something community groups do not possess vis-à-vis housing development. More specifically, it requires know-how in making detailed assessments of the nature of the market demand for a particular housing development, coordinating all of the professional inputs required, unravelling bureaucratic red tape, obtaining sites, financing, judging construction contractors, and performing a myriad of other activities too numerous to list. ${ }^{41}$ One consideration of concern to private and community developers alike is whether to contract out for the various skills required or to retain in-house staff attorneys, accountants, financial analysts, and the like. Most community group developers have followed neither route but instead have relied on volunteer experts while forming staffs of community organizers. This has resulted in conflicts of interest, which will be discussed in detail in part IV.

\section{Construction Skills}

Very few private developers are so vertically integrated as to have operating subsidiaries which actually function as general contractors in the building of housing developments. Usually they and the community groups developing housing

\footnotetext{
${ }^{10}$ The most direct federal housing assistance would be providing income to the poor. Id. at 1373 . However, would this result in more housing, or just higher prices for existing housing?

'1 See Moses, Rental Housing for Low-Income Families Under Section 236, in PrIVate Capital aND Low Income Housing 28 ( 1969 ), for an excellent description of the developing process.
} 
delegate to others this phase of development. From the standpoint of feasibility, how much delegation can be accomplished in an inner-city setting? Ghetto communities are justifiably antagonistic to the construction trades because of their wellpublicized discriminatory hiring and apprenticeship policies, and the picketing by residents of such desperately needed municipal service centers as new hospital facilities, as well as housing construction sites, is not unknown. Moreover, existing construction industry building practices reflect a resistance to technological change, and in some cities this source of savings may be the only hope of bringing housing developments within allowable cost limits. ${ }^{42}$

\section{Management Competence}

Once a low-income rental housing development is ready for occupancy, what management role should a community group assume? It is quite obvious that the interests of the manager and tenants are somewhat conflicting. Would full disclosure of this fact and its ramifications to the tenants help here, or should community groups simply decline housing management responsibilities? Some equity investors and mortgagees may be unwilling to invest financially in a low-income housing development unless some community group acts as a buffer to assuage some of the basically economic tensions implicit in the landlord-tenant relationship. Such a prospective investor may require that a community group assume certain defined responsibilities to identify and resolve possible community "problems" which cannot themselves be defined with any precision. Thus the group may actually have no choice about participating in management.

\section{The Uncertainty of "Community"}

In the case of business development, the inner city is an inhospitable locus for investment, especially when contrasted with alternative investment possibilities. However, as was noted previously, at least with low-income housing development, investment factors such as costs, the market for the product, and the return on investment can be calculated rather precisely. What cannot be estimated in advance in terms of cost, and can only be vaguely articulated, is the significant risk which might come under the heading of community antagonism. An insensitive observer, without acquired insights into the frustrations and reactions caused by promises made to ghetto residents but never kept, would term it "irrationality."

By way of illustration, why do community groups continue to espouse the cause of rent control? By now, the evidence is overwhelming that rent control is totally counterproductive to an increase in and an upgrading of the existing stock of lowincome housing and thus frustrates a resolution of the housing problems of inner

\footnotetext{
${ }^{43}$ Although savings obtainable from cheaper and more efficient construction methods are potentially not that significant in relation to total development costs, they may be the difference between feasibility or non-feasibility. Moreover, if more efficient methods result in savings in time, financing costs will of course be reduced.
} 
cities. $^{43}$ Yet, sophisticated and well-intentioned ghetto leaders continue to lobby for rent control. More in point might be, for example, a demand by a community constituency for a day care center to be provided for each twenty-five units of housing, although the inclusion of such an amenity might result in the project being not feasible and no housing being built. Such a situation might arise at the beginning of planning or, to the dismay of a private developer, perhaps after significant amounts of seed money had been paid out. When this or a similar demand is voiced the issue usually assumes political ambiguities, and negotiations would proceed in a vacuum without reference to the economics. What role should a community group assume in such a case?

IV

\section{Community Group Decision-Making and Low-Income}

\section{Housing Development}

The purpose of this portion of the analysis is not a catalog of "how to do lowincome housing development by community groups." Such an exposition is best left to the handbooks, of which there are several. There are differences between the development of low-income and other than low-income housing but, for the most part, the experience of developers of housing for the more affluent is relevant for community groups. The technical processes of packaging, site selection, financing, and construction vary little from luxury apartment development to low-income rental housing. Moreover, as soaring costs necessitate governmental assistance in the production of housing for those in higher income brackets, the differences will become insignificant.

There are, however, some issues, as contrasted with the technical processes once a project is underway, which require a community consensus of some sort when low-income housing development is being considered. How to achieve the consensus and who should participate in educating and being educated as to these issuesthe community leaders, prospective tenants, or others-are questions best decided by individual communities themselves.

\section{A. Should a Community Group Develop Low-Income Housing?}

From the perspective of money profits to a community group, the answer is obviously yes. There are, however, other considerations. This issue requires some analysis of the interests involved in low-income housing development. The financial investors, the providers of the equity, the mortgage banker, and the party who subsidizes it all, the government, are variously concerned with the return on and the security of their business investment. The tenant, who perhaps tolerated previous housing which was substandard and expensive, does not view himself in a business context as the purchaser of housing but rather regards his occupancy as a right

\footnotetext{
${ }^{18}$ See Rental Houstng in New York City: Confronting the Crists i2-I4 (I. Lowiy ed. Ig69).
} 
of sorts; and he can be readily organized, for example, to participate in a rent strike even if justifiable rent increases are proposed. ${ }^{44}$ And without the participation of a third group, low-income housing will not be developed. This group is the community leadership, which operates the community organization the approval of which will be a prerequisite to outside investment. What the outside investors desire is a joint venture between themselves and the community leadership group, the latter's function being to resolve the uncertainties of the particular community. The community group will be reimbursed for its efforts from the profits of the venture, and it might, for example, allocate these monies to rent reductions. In effect, the community group represents two potentially conflicting interests. The problem is exacerbated if the community group, assuming available financing and expertise, proceeds to develop housing on its own. It may be impossible for a community group which develops housing to retain the confidence of the community at large, there being a conflict of interest between "getting the project developed successfully" and being an advocate of perceived community interests. It is questionable whether such a problem can be resolved simply through communityoriented structures such as a board of directors elected at-large from the community and overseeing the activities of the solo or joint sponsors.

The remaining alternative is having a truly representative community leadership group canvass a community in advance or in response to a proposal by private developers and draft acceptable specifications for low-income housing development ratified by the community at large. The problem of specifications changed in the negotiations could then be resolved by another resort to community approval.

\section{B. Where to Locate?}

Perhaps it has been implied by this analysis that a low-income housing development should take place in the inner city. This may not be the most appropriate choice from the perspectives of costs and other equally important social factors. Sufficient land at a reasonable price may not be available in the ghetto. Real property taxes may be too high to bring rents within acceptable levels. Adverse environmental factors of extensive physical blight, high crime rates, and poor municipal and human services may make it unwise to develop in a section of an inner city where a completed project will sink to the level of its surroundings in a few years. In other words, it may be unwise to be the first one in. The bulldozer may be the only viable alternative short of increased Model Cities appropriations. Most importantly, the dilemma and results of continuing segregated residential patterns should be seriously considered.

Is it possible to locate a low-income development in suburbia? The first problem with this approach is that there is a need, and thus a political demand, for low-

\footnotetext{
"For a general study of tenant attitudes, see Transitjon Neighiorhoods in New York Citr: The People's View of Their Housing Environment (Vera Institute of Justice, x969).
} 
income housing for those poor already residing in the suburbs. ${ }^{45}$ Moreover, multifamily rental housing, which may be the only feasible way to proceed at reasonable cost, might be blocked by restrictive land use practices. And rural or new town development, exemplified by the "New Communities" approach, appears doomed to failure unless employment, transportation, and other services are first provided.

Perhaps the most feasible choice, after all, is to build in an inner-city location, while undertaking measures to attract white, middle-class residents. What has come to be known as rent skewing might be the answer. It would be more ideologically acceptable to some ghetto leaders if for every white occupant relocating to such a development, a low-income resident displaced from possible occupancy could move to the area from which the white resident relocated.

\section{New Construction or Rehabilitation Projects?}

A factor, in addition to the obvious ones of cost and feasibility, bearing on the decision to engage in new construction or rehabilitation is the dilemma of relocation. In some municipalities, new construction costs may be prohibitive. However, rehabilitation expenses have been known in some instances to exceed costs of new construction, and the chief factor in holding such costs down appears to be rehabilitation projects sufficiently large to achieve economies of scale-and this causes relocation problems. Perhaps the only solution to relocation problems in such a case is reserve housing, which is probably unrealistic, or rehabilitation which is conducted sequentially.

\section{Home Ownership or Rental Housing and Tenant Management?}

With more recent federal programs, government-assisted home ownership for low-income families is possible even in the context of multi-unit developments. ${ }^{46}$ The question then becomes one of determining what the prospective occupants of the intended housing prefer. If only multifamily development is feasible, do the low-income consumers desire ownership of such housing, or are they thinking of something else, perhaps in suburbia?

Assuming a decision is made to proceed with multi-unit rental housing, the community group must must still consider the desirability of performing management functions. ${ }^{47}$ The possible problems here are quite similar to those hypothesized when a community group develops housing. The final decision will revolve upon whether the tenants or the community groups desire to be the managers and whether one would be more appropriate in that function than the other.

\footnotetext{
${ }^{25}$ See The STATE AND THE PoOR (S. Beer \& R. Barringer eds. 1970), for convincing evidence that many suburban communities have in the aggregate more resident poor than the inner cities they surround.

${ }^{40} \mathrm{It}$ is by no means established that low-income families would prefer home ownership. Transition Neighborhoods in New YoRr CiTY, supra note 44 , at 84 .

${ }^{47}$ In a survey conducted in New York, as many tenants preferred the city as landlord as preferred a community group landlord. Id. at 95 .
} 


\section{Conctusion}

It seems that low-income housing development is at least an effective and efficient additional strategy to achieve community economic development. The economic certainty contrasts most favorably with the financial risks inherent in inner-city business development. To be sure, the community "risks" are formidable and the accommodations that must be worked out are complicated. 